\title{
PENGEMBANGAN METODA ELEKTROLISIS GAS HHO SEBAGAI SUPLEMEN PADA KOMPOR LPG MENGGUNAKAN SEL SURYA
}

\author{
Hartono Budi Santoso', Sapto Prajogo ${ }^{2}$ \\ Jurusan Teknik Konversi Energi - Politeknik Negeri Bandung \\ Email : 'hartono@esi-labs.com, ${ }^{2)}$ saptoprajogo@gmail.com
}

\begin{abstract}
Abstrak
Krisis energi konvensional menyebabkan harga energi konvensional menjadi mahal.Oleh sebab itu penggunaan hidrogen sebagai suplemen pada kompor LPG diharapkan mampu mereduksi konsumsi LPG. Potensi energi hidrogen sangat berlimpah di alam dan sering dijumpai dalam bentuk air.Air kemudian dipecah menjadi hidrogen dan oksigen dengan metoda elektrolisis, dan alat yang digunakan disebut sel elektroliser.

Elektroliser mengubah air menjadi gas HHO melalaui proses elektrolisisdengan daya input berupa listrik DC dan kemudian diaplikasikan pada sistem kompor LPG sebagai suplemen agar dapat menghemat konsumsi LPG.Namun, karena harga listrik yang masih mahal, maka digunakan sel surya sebagai bentuk energi alternative dan agar penghematan LPG dapat tercapai.

Pengujian dilakukan dengan melakukan pengukuran konsumsi LPG dengan dan tanpa gas HHO untuk memanaskan 1 liter air dengan kenaikan temperatur hingga $45^{\circ} \mathrm{C}$. Hasil pengujian menunjukan dengan ratarata irradiasi $633 \mathrm{~W} / \mathrm{m} 2$ dan daya input elektroliser rata-rata 43,91 2(dari data) $\mathrm{W}$ dapat menghemat konsumsi LPG hingga $27,27 \%$.
\end{abstract}

Bukan iiradiasi tapi fluks radiasi

Kata kunci: elektroliser, gas HHO, LPG, elektrolisis, sel surya.

\section{PENDAHULUAN}

Manusia hidup sangat tergantung pada energi, baik dalam skala rumah tangga maupun industri. Saat ini total kebutuhan energi di seluruh dunia mencapai 10 Terra Watt dan diperkirakan akan terus meningkat hingga 30 Terra Watt pada tahun 2030[1]. Krisis ini terjadi lantaran penggunaan besarbesaran energi yang tidak berimbang dengan kapasitas energi fosil di alam. Ketergantungan manusia akan energi tidak bisa dijamin oleh energi fosil di masa yang akan datang.

$\mathrm{Di}$ Indonesia, setelah terjadi kelangkaan energi minyak bumi untuk kompor minyak, pemerintah mengalihkan energi minyak bumi ke LPG (Liquid Petrolioum Gas) menjadi kompor gas. Namun besarnya konsumsi bahan bakar LPG ini sudah tidak bisa diimbangi dengan cadangan gas alam yang tersedia, ini dikarenakan sifatnya yang tidak terbarukan, selain itu juga harga LPG semakin meningkat. Oleh sebab itu penghematan atas energi gas LPG ini perlu dilakukan. Penghematan bisa dilakukan dengan cara mengurangi konsumsi energi gas LPG, yang artinya memasak sesuatu dengan menggunakan gas LPG perlu dikurangi.
Namun hal tersebut bukanlah solusi dan tidak efektif.Yang diinginkan adalah bagaimana kebutuhan untuk menggunakan LPG tetap terpenuhi namun dalam penggunaannya dapat menghemat sebesar mungkin konsumsi LPG.

Alternatif energi yang dapat menjadi suplemen untuk menghemat bahan bakar LPG dalam rumah tangga adalah pemanfaatan gas HHO yang terbentuk dari proses elektrolisis. Gas $\mathrm{HHO}$ atau disebut brown gas merupakan campuran gas hidrogen dan oksigen dengan proses elektrolisis larutan air. Secara umum, elektrolisis air menghasilkan gas hidrogen di katoda dan oksigen di anoda. Gas HHO ini merupakan "gas air" yang mana gas hidrogen dan gas oksigen tercampur. Pada proses elektrolisis dibutuhkan energi listrik dari luar. Sebagai alternatif sumber energi listrik maka dapat memanfaatkan panel surya. Salah satu pemanfaatan gas $\mathrm{HHO}$ antara lain sebagai alternatif bahan bakar kendaraan bermotor sesuai hasil kajian tentang pengaruh pemberian frekuensi listrik pada pemanfaatan gas HHO sebagai bahan bakar kendaraan bermotor [2]. Sementara Nu'man dan Indra H.S. (2013) melakukan kajian tentang pemanfaatan LPG sebagai bahan bakar 
kendaraan bermotor dengan penambahan gas HHO untuk meningkatkan performa [3]. Kajian tentang pengaruh pemberian $\mathrm{NaHCO}_{3}$ terhadap produksi gas $\mathrm{HHO}$ yang dikaji oleh Ena M., Slamet W. dan Lilis Y. (2013), hasil kajian menunjukan jumlah energi yang diperlukan untuk proses elektrolisis dan laju produksi gas $\mathrm{HHO}$ meningkat seiring dengan bertambahnya prosentase $\mathrm{NaHCO}_{3}$ (Natrium Bikarbonat), dan mencapai nilai maksimum pada prosentase $\mathrm{NaHCO}_{3}$ sebesar $12,5 \%$ [4].

Pada penelitian ini akan dilakukan kajian tentang pemanfaatan gas $\mathrm{HHO}$ untuk mengurangi penggunaan bahan bakar LPG pada kompor gas dengan memanfaatkan solar panel sebagai sumber listrik DC yang dibutuhkan dalam proses elektrolisis.

\section{TINJAUAN PUSTAKA}

\section{Proses Elektrolisis}

Elektroisis air merupakan peristiwa penguraian senyawa air $\left(\mathrm{H}_{2} \mathrm{O}\right)$ menjadi oksigen $\left(\mathrm{O}_{2}\right)$ dan gas hidrogen $\left(\mathrm{H}_{2}\right)$ dengan menggunakan arus listrik. Reaksi tersebut dapat dituliskan dengan persamaan sebagai berikut:

$$
2 \mathrm{H}_{2} \mathrm{O}_{(\mathrm{l})} \rightarrow 2 \mathrm{H}_{2(\mathrm{~g})}+\mathrm{O}_{2(\mathrm{~g})}
$$

Terjadi tekanan listrik pada elektroda negatif (katoda) untuk mendorong elektron ke dalam air dan pada elektroda positif (anoda) terjadi penyerapan elektron. Molekul air dekat katoda menjadi ion hidrogen positif $\left(\mathrm{H}^{+}\right)$dan ion hidroksida $\left(\mathrm{OH}^{-}\right)$.

$$
\mathrm{H}_{2} \mathrm{O} \rightarrow \mathrm{H}^{+}+\mathrm{OH}^{-}
$$

$\mathrm{H}^{+}$merupakan proton terbuka dan bebas untuk menangkap elektron $\mathrm{e}^{-}$dari katoda, kemudian menjadi atom hidrogen biasa dan netral.

$$
\mathrm{H}^{+}+\mathrm{e}^{-} \rightarrow \mathrm{H}
$$

Atom hidrogen ini kemudian bergabung dengan atom hidrogen lain dan membentuk molekul gas dalam bentuk gelembung dan kemudian naik ke permukaan.

$$
\mathrm{H}+\mathrm{H} \rightarrow \mathrm{H}_{2}
$$

Elektroda positif telah menyebabkan ion hidroksida $\left(\mathrm{OH}^{-}\right)$bergerak ke anoda. Ketika mencapai anoda, anoda melepas kelebihan elektron yang diambil oleh hidroksida dari atom hidrogen sebelumnya, kemudian ion hidroksida bergabung dengan molekul hidroksida yang lain dan membentuk satu molekul oksigen dan dua molekul air.

$$
4 \mathrm{OH}^{-} \rightarrow \mathrm{O}_{2}+2 \mathrm{H}_{2} \mathrm{O}+4 \mathrm{e}^{-}
$$

Dan kemudian molekul gas oksigen ini naik ke permukaan. Demikianseterusnya dan terjadi pengulangan proses. Gas hidrogen dan oksigen yang dihasilkan dari reaksi ini dapat dikumpulkan untuk kemudian digunakan sebagai bahan bakar.

Karakteristik dari gas HHO diantarnya adalah:

1. Memiliki kandungan energi yang tinggi dan mampu menghasilkan nyala api dingin (cold flame) dengan potensial energi yang tinggi apabila dibakar.

2. Mempu menyalurkan energi ke sebuah material dalam bentuk struktur atom.

3. Mudah dikendalikan, tidak berbau dan tidak berbahaya terhadap tubuh manusia bahkan apabila terhirup sekalipun.

4. Dapat berdifusi dengan udara dengan cepat

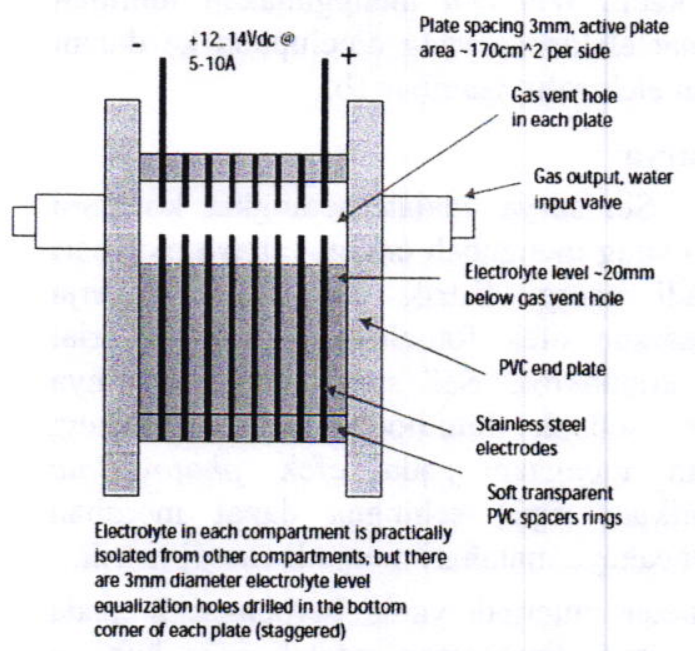

(a)

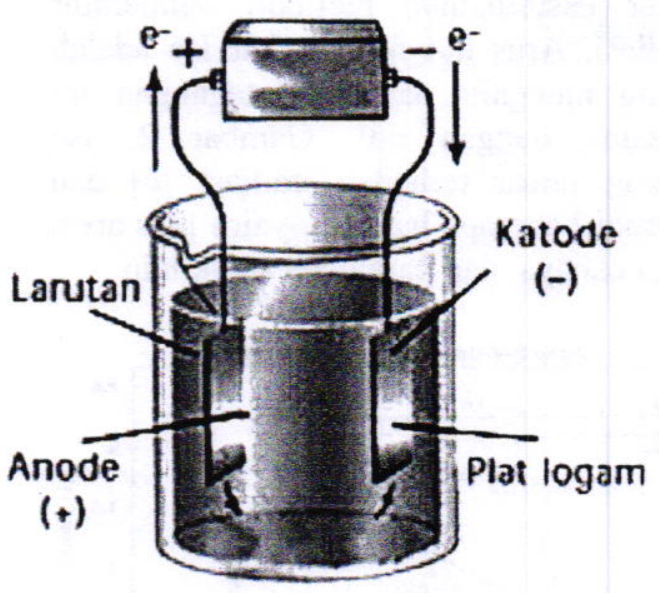

(b)

Gambar 1. a. Dry Cell Electrolyzer [5] b. Wet Cell Electrolyzer 
Elektroliser adalah perangkat yang digunakan untuk proses elektrolisis. Perangkat ini terdiri dari elektroda yang dialiri arus dc untuk mengurai larutan elektrolit. Menurut Faraday tegangan minimal untuk proses elektrolisis dengan konfigurasi sederhana yaitu dua buah elektroda adalah $1,24 \mathrm{~V}$, sedangkan menurut Yull Brown adalah 1,48 V, dan menurut Boyce 2-3 volt. Dengan demikian semakin besar tegangan sumber maka dapat digunakan plat lebih banyak, sehingga dapat menghasilkan hidrogen lebih banyak pula. Elektroliser terbagi menjadi dua jenis, yaitu dry cell dan wet cell. Dry cell atau sel kering adalah elektroliser dengan menggunakan multi elektroda, Gambar 1a, perangkat ini mengurai larutan elektrolit per-sekat dengan volume yang kecil. Wet cell menggunakan minimal dua plat elektroda yang dicelupkan ke dalam larutan elektrolit, Gambar 1b.

\section{Sel Surya}

Sel surya adalah perangkat konversi energi yang mengubah energi cahaya matahari menjadi energi listrik. Sel surya bekerja berdasarkan efek fotoelektrik pada material semi konduktor. Sel surya pada dasarnya adalah sebuah fotodioda yang dirancang dengan mengacu pada efek photovoltaic sedemikian rupa, sehingga dapat merubah energi cahaya matahari menjadi energi listrik.

Parameter internal yang berpengaruh pada kurva daya diantaranya adalah arus hubung singkat dan tegangan tanpa beban. Sedangkan parameter eksternalnya meliputi temperatur dan iradiasi. Arus hubung singkat Isc adalah arus yang mengalir pada saat tegangan sel surya sama dengan nol, Gambar 2. Isc bergantung linear terhadap iradiasi [6] dan dipengaruhi beberapa hal lain, yaitu luas area, spektrum cahaya, dan parameter optik lain.

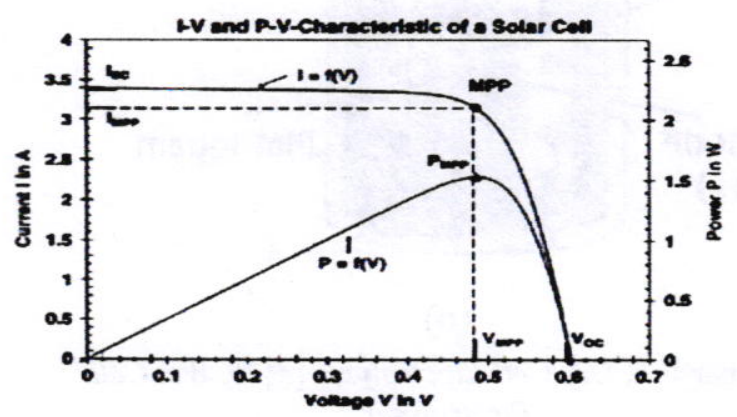

Gambar 2. Kurva Karakteristik Hubung Singkat
Tegangan panel tanpa beban, Voc adalah tegangan maksimum dari sel surya dan terjadi saat arus sel sama dengan nol. Tegangan ini merupakan kondisi panjar maju pada junction sel surya.

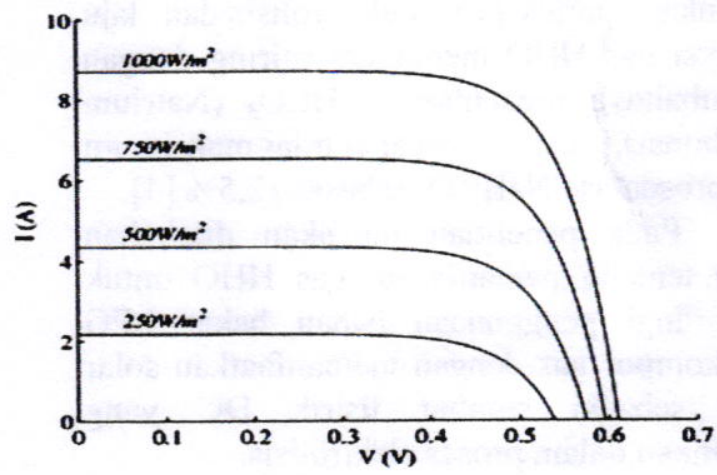

Gambar 3. Pengaruh Iradiasi Terhadap Kurva Karakteristik V-I

Irradiance atau iradiasi karena satuan ini? yang biasa digunakan untuk perhitungan efisiensi dari sel surya. Iradiasi merupakan sumber energy bagia sel surya, maka daya keluaran sel surya sangat bergantung pada iradiasi. Dapat dilihat dari Gambar 3. bahwa daya keluaran sel surya berbanding lurus dengan iradiasi [7]. Isc lebih terpengaruh oleh perubahan iradiasi daripada Voc.

\section{Metoda Penelitian Percobaan}

Penelitian ini menggunakan metode eksperimental (experimental method). Pada penelitian ini akan dilakukan pengukuran konsumsi gas LPG yang dibutuhkan untuk memanaskan $1 \mathrm{~L}$ air dengan kenaikan temperatur hingga $45^{\circ} \mathrm{C}$. Selanjutnya dilakukan perbandingan besar konsumsi LPG pada saat menggunakan dan tidak menggunakan gas $\mathrm{HHO}$, yang dihasilkan dari proses elektrolisa $500 \mathrm{ml}$ air yang telah dicampurkan $\mathrm{KOH}$, yang mengalir dari water tank menuju elektroliser (Gambar 4.) Elektroliser talu akan meng-elektrolisis larutan air tersebut dengan daya input DC dari sel surya $50 \mathrm{Wp}$ sehingga menghasilkan gas $\mathrm{HHO}$ (oxyhydrogen). Gas ini kemudian dialirkan menuju $Y$ connector yang dimodifikasi untuk mencegah gas LPG masuk ke sistem elektroliser. Lalu di $Y$ connector gas $\mathrm{HHO}$ dicampurkan oleh gas LPG. Variabel yang diamati antara tegangan, arus, radiasi matahari dan waktu yang dibutuhkan untuk memanaskan air. 


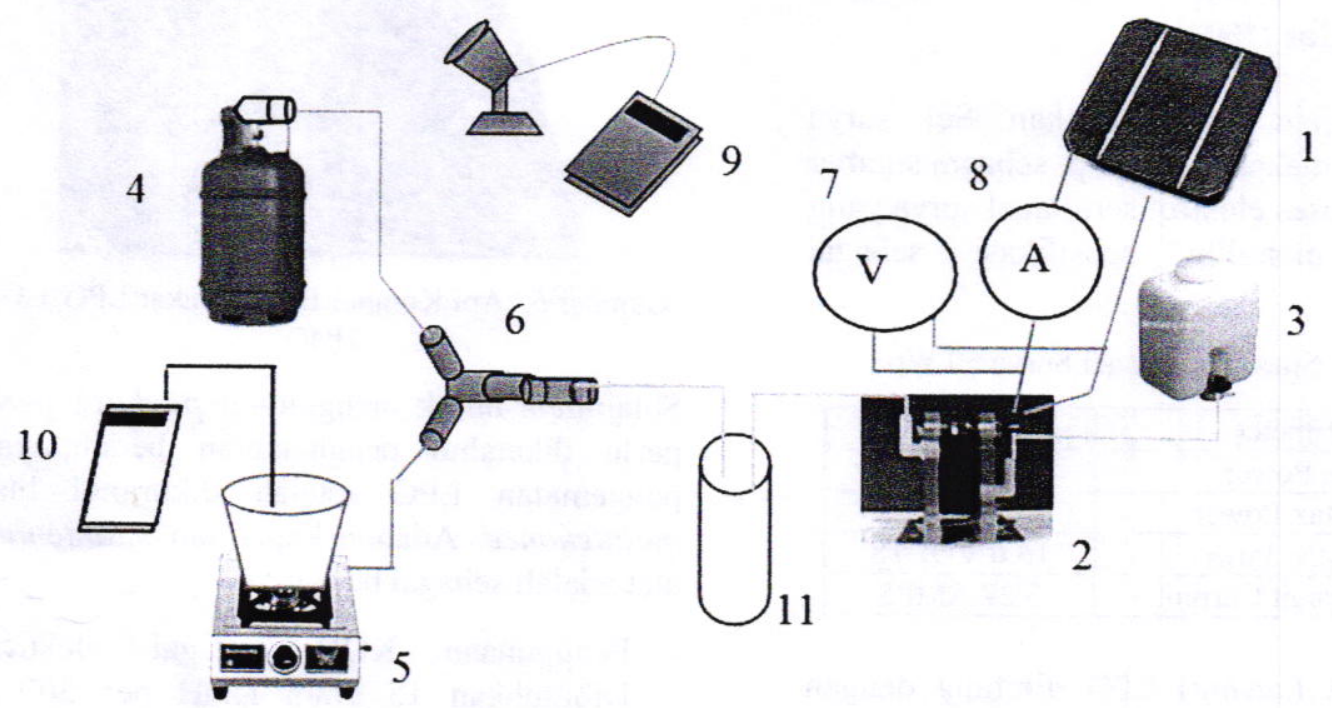

Gambar 4. Skema pengujian Kompor LPG dengan penambahan gas HHO

Keterangan :

1. Sel surya

2. Dry cell electrolyzer

3. Water tank

4. LPG
5. Kompor

6. Modified Y connector

7. Voltmeter

8. Amperemeter
9. Phyranometer

10. Termometer

11. bubbler

Tabel 1. Data Percobaan Konsumsi Gas LPG Tanpa Gas HHO

\begin{tabular}{|c|c|c|c|c|c|c|c|c|c|}
\hline No & $\mathrm{m} 0(\mathrm{~kg})$ & $\mathrm{ml}(\mathrm{kg})$ & $\Delta \mathrm{m}(\mathrm{kg})$ & $\begin{array}{l}\Delta \bar{m} \\
(\mathrm{~kg})\end{array}$ & $\mathrm{T} 0\left({ }^{\circ} \mathrm{C}\right)$ & $\begin{array}{c}\mathrm{T} 1 \\
\left({ }^{\circ} \mathrm{C}\right)\end{array}$ & $\begin{array}{c}\Delta \mathrm{T} \\
\left({ }^{\circ} \mathrm{C}\right)\end{array}$ & $t(s)$ & $t(s)$ \\
\hline 1 & 6.46 & 6.445 & 0.015 & \multirow{4}{*}{0.014} & 27.2 & 72.2 & 45 & 253 & \multirow{4}{*}{266.5} \\
\hline 2 & 6.445 & 6.43 & 0.015 & & 27.4 & 72.4 & 45 & 275 & \\
\hline 3 & 6.43 & 6.42 & 0.01 & & 27.7 & 72.7 & 45 & 269 & \\
\hline 4 & 5.98 & 5.965 & 0.015 & & 28.5 & 73.5 & 45 & 269 & \\
\hline
\end{tabular}

\section{HASIL DAN PEMBAHASAN}

\section{Pengujian Kompor LPG Tanpa Campuran Gas HHO}

Data hasil pengujian kompor LPG tanpa campuan gas HHO disajikan pada T tabel 1 . Hasil pengujian menunjukan bahwa untuk memanaskan $1 \mathrm{~L}$ air hingga temperaturnya naik sebanyak $45^{\circ} \mathrm{C}$, dibutuhkan massa LPG rata-rata sebanyak $0,01375 \mathrm{~kg}$ dengan waktu rata-rata 326,5 detik.

Gambar 5. menunjukkan warna nyala api ketika percobaan memanaskan air oleh kompor dengan bahan bakar hanya menggunakan LPG. Terlihat bahwa warna nyala api didominasi dengan warna biru dengan sedikit warna merah diujung lidah api, ini menunujukkan kualitas api yang bagus dimana campuran bahan bakar dan oksigen mendekati stokiometri.

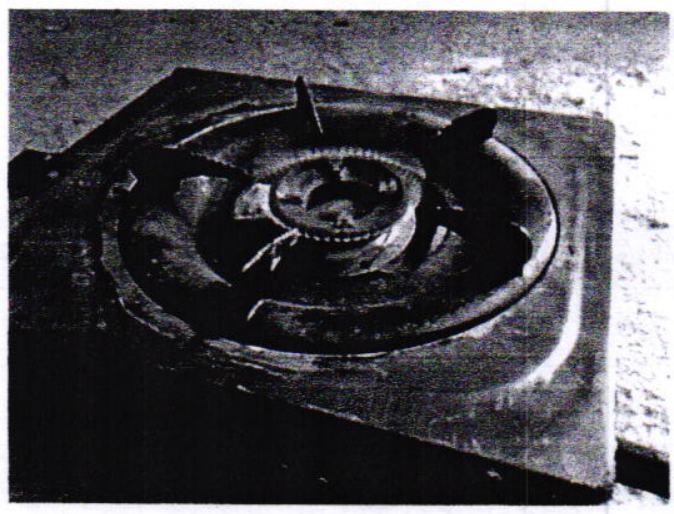

Gambar 5. Api Kompor Bahan Bakar LPG 


\section{Pengujian Kompor LPG Dengan Tambahan Gas HHO}

Pada pengujian ini digunakan Sel surya dengan daya maksimal $50 \mathrm{Wp}$, sebagai sumber DC untuk proses elektroliser. Panel surya yang digunakan memiliki spesifikasi sebagai berikut:

Tabel 2. Spesifikasi Panel Surya $50 \mathrm{Wp}$

\begin{tabular}{|c|c|}
\hline Parameter & Nilai \\
\hline Max Power & 49 WATTS \\
\hline I @ Max Power & 3.06 AMPS \\
\hline V @ Max Power & 16.0 VOLTS \\
\hline Short Circuit Current & 3.27 AMPS \\
\hline
\end{tabular}

Penghematan (saving) LPG dihitung dengan persamaan :

$$
\frac{\mathrm{m} 1-\mathrm{m} 2}{\mathrm{~m} 1} \%
$$

Data hasil pengujian seperti tampak pada tabel 3. Hasil pengujian menunjukan warna api yang terbentuk, dapat dilihat pada Gambar 4.3, warna nyala api didominasi dengan warna merah, ini menunjukkan bahwa kualitas api menurun. Hal tersebut dikarenakan perbandingan oksigen dan bahan bakar tidak bagus dan hal tersebut adalah sebagai reaksi dari hasil pembakaran yang berupa panas dan uap air. Namun lidah api yang terbentuk dari penambahan gas HHO lebih besar maka waktu yang butuhkan untuk memanaskan airpun berkurang. Penambahan gas $\mathrm{HHO}$ pada sistem kompor LPG mampu menghemat konsumsi LPG hingga $27,27 \%$. Seperti tampak pada tabel 3.

Dengan debit rata-rata yaitu $1.64 \mathrm{ml} / \mathrm{s}$ maka, dalam sehari elektroliser mampu menghasilkan gas HHO sebanyak $29640 \mathrm{ml}$ atau 29,64 L. Jumlah tersebut dinilai cukup untuk dapat menghemat $27,27 \%$ konsumsi LPG dalam sehari.

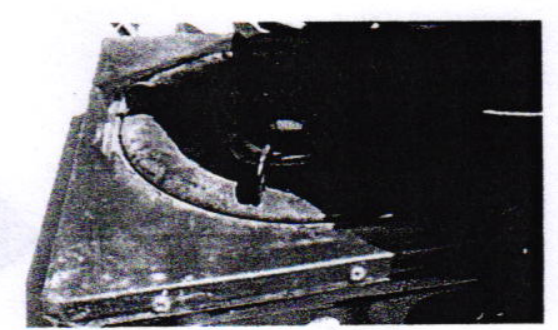

Gambar 6. Api Kompor Bahan Bakar LPG + Gas $\mathrm{HHO}$

Selajutnya untuk menghitung payback period perlu diketahui penghematan bersih, yaitu pengematan LPG setelah dikurangi biaya maintenance. Adapun keperluan maintenance alat adalah sebagai berikut:

- Penggunaan KOH sebagai elektrolit. Dibutuhkan 15 gram $\mathrm{KOH}$ per $500 \mathrm{ml}$ aquades dengan asumsi waktu pemakaian satu minggu per larutan tersebut. Maka dalam setahun dibutuhkan $\mathrm{KOH}$ sebanyak 720 gram KOH. Jika harga $\mathrm{KOH}$ adalah Rp 32.000 ,- per kg, maka:

Penggunaan $\mathrm{KOH} 1$ tahun = $\frac{720 \text { gramxRp 15.000,- }}{1000 \text { gram }}=$ Rp 10.800,-

- Penggunaan aquades. Dibutuhkan $500 \mathrm{ml}$ aquades untuk sebuah elektrolit. Dengan asumsi waktu pemakaian yang sama seperti penggunaan $\mathrm{KOH}$, maka dalam setahun penggunaan aquades adalah $24000 \mathrm{ml}$ atau $24 \mathrm{~L}$. Jika harga aquades per liter adalah $\mathrm{Rp}$ 1.500 ,- maka dalam setahun menghabiskan biaya:

Penggunaan aquades 1 tahun $=24 \times \mathrm{Rp}$ $36.000,-=\operatorname{Rp} 36.000,-$

Dengan demikian total biaya maintenance per tahun adalah Rp 46.800,-/tahun.

Jika harga investasi berupa sel surya $50 \mathrm{Wp}$ dengan harga Rp 460.000,-dan investasi elektroliser adalah Rp 160.000,- maka payback period dapat dihitung dengan cara berikut:

Tabel 3. Konsumsi LPG Dengan Tambahan Gas HHO

\begin{tabular}{|c|c|c|c|c|c|c|c|c|c|c|c|c|c|}
\hline T0 $\left({ }^{\circ} \mathrm{C}\right)$ & $\mathrm{T} 1\left({ }^{\circ} \mathrm{C}\right)$ & $\Delta \mathrm{T}\left({ }^{\circ} \mathrm{C}\right)$ & ml (kg) & $\mathrm{m} 2(\mathrm{~kg})$ & $\Delta \mathrm{m}(\mathrm{kg})$ & $V(V)$ & I (A) & $\begin{array}{c}\overline{\mathrm{P}} \\
(\mathrm{W})\end{array}$ & irr $\left(W / m^{2}\right)$ & $\begin{array}{l}\text { Av irr } \\
\left(\mathrm{W} / \mathrm{m}^{2}\right)\end{array}$ & $t(s)$ & $\bar{t}(s)$ & saving (\%) \\
\hline 26.9 & 71.9 & 45 & 6.35 & 6.34 & 0.01 & 8 & 5.4 & \multirow{4}{*}{43.92} & 628 & \multirow{4}{*}{633} & 266 & \multirow{4}{*}{256.25} & $27.27 \%$ \\
\hline 28.4 & 73.4 & 45 & 6.34 & 6.33 & 0.01 & 8 & 5.5 & & 632 & & 247 & & $27.27 \%$ \\
\hline 29.6 & 74.6 & 45 & 6.33 & 6.32 & 0.01 & 8 & 5.5 & & 634 & & 258 & & $27.27 \%$ \\
\hline 28.4 & 73.4 & 45 & 6.3 & 6.29 & 0.01 & 7.8 & 5.7 & & 638 & & 254 & & $27.27 \%$ \\
\hline
\end{tabular}


Rata-rata kepala keluarga di Indonesia menghabiskan $0,3 \mathrm{~kg}$ LPG setiap hari atau artinya dapat menghabiskan LPG $3 \mathrm{~kg}$ selama10 hari atau LPG $12 \mathrm{~kg}$ selama 40 hari. Itu artinya dalam setahun konsumsi LPG bisa mencapai $109,5 \mathrm{~kg}$ yaitu setara dengan 36,5 atau 37 buah gas LPG $3 \mathrm{~kg}$, atau jika dikonversikan dalam tabung $12 \mathrm{~kg}$ adalah sekitar 9,125 atau 10 buah. Jika harga gas $3 \mathrm{~kg}$ adalag Rp 25.000,- dan gas $12 \mathrm{~kg}$ adalah $\mathrm{Rp}$ 142.000 ,- maka dalam setahun menghabiskan biaya sebanyak:

Biaya gas $3 \mathrm{~kg} 1$ tahun $=37 \times \mathrm{Rp} 25.000$,- = Rp 925.000,-

Biaya gas $12 \mathrm{~kg} 1$ tahun $=10 \times \mathrm{Rp} 142.000,-=$ Rp 1.420.000,-

Diketahui bahwa gas HHO dapat menghemat LPG sebanyak $27,27 \%$, maka konsumsi dapat berkurang menjadi $0,21819 \mathrm{~kg}$ per hari. Itu artinya menambahkan gas $\mathrm{HHO}$ akan menghabiskan gas LPG selama:

Lama konsumsi gas $3 \mathrm{~kg}=\frac{3 \mathrm{~kg}}{0,21819 \mathrm{~kg} / \text { hari }}$ $=13,74$ hari

Lama konsumsi gas $12 \mathrm{~kg}=\frac{12 \mathrm{~kg}}{0,21819 \mathrm{~kg} / \mathrm{hari}}$ $=54,99$ hari

Dan dalam setahun konsumsi $\mathrm{LPG}=0,21819$ $\mathrm{kg}$ per hari $\times 365 \mathrm{hari}=79,63 \mathrm{~kg}$ per tahun

Artinya hanya menghabiskan $=\frac{79,63 \mathrm{~kg} / \text { tahun }}{3 \mathrm{~kg}}=$ 26,5 atau 27 buah gas LPG $3 \mathrm{~kg}$ per tahun, atau $\frac{79,63 \mathrm{~kg} / \text { tahun }}{12 \mathrm{~kg}}=6,6$ atau 7 buah LPG 12 $\mathrm{kg}$ per tahun.

Dengan demikian dalam setahun menghabiskan biaya:

Biaya gas $3 \mathrm{~kg} 1$ tahun (dengan penghemat)

$=27 \times \operatorname{Rp} 25.000,-=\operatorname{Rp} 675.000$,-

Biaya gas $12 \mathrm{~kg} 1$ tahun (dengan penghemat)

$=7 \times \operatorname{Rp~142.000,-}=\operatorname{Rp} 994.000$,-

diketahui rata-rata mass flow LPG adalah $5,15 \times 10^{-5} \mathrm{~kg} / \mathrm{s}$, dengan konsumsi LPG yaitu $0,3 \mathrm{~kg}$ per hari, maka lama waktu pemakaian per hari adalah 5814 detik atau kurang lebih 96 menit.

Elektroliser menghasilkan rata-rata $4,8 \mathrm{ml} / \mathrm{s}$ gas HHO dengan daya dari sel surya $200 \mathrm{wp}$. Dan pada percobaan sebelumnya dalam sehari elektroliser dapat menghasilkan kurang lebih $67 \mathrm{~L}$ gas HHO. Sedangkan kebutuhan gas HHO per hari untuk menghemat gas LPG sebanyak $27,27 \%$ adalah:

Kebutuhan gas $\mathrm{HHO}=$ debit $\mathrm{HHO} \times$ lama pemakaian per hari
$=4,8 \mathrm{ml} / \mathrm{s} \mathrm{x} 5814 \mathrm{~s}=28242,07 \mathrm{ml}(28,24 \mathrm{~L})$

Sehingga dibutuhkan setidaknya $35 \mathrm{~L}$ gas $\mathrm{HHO}$ per hari agar dapat menghemat konsumsi LPG hingga $27,27 \%$.

Asumsi bahwa radiasi matahari konstan menyinari bumi pada pukul $10.00-14.00$ yang berarti selama 5 jam atau 18000 detik. Maka, untuk mencapai $35 \mathrm{~L}$ per hari dibutuhkan laju alir gas $\mathrm{HHO}$ sebanyak:

Laju alir $\mathrm{HHO}=35000 \mathrm{ml} / 18000 \mathrm{~s}=1,94$ $\mathrm{ml} / \mathrm{s}$.

Untuk mendapatkan $35 \mathrm{~L}$ gas $\mathrm{HHO}$ per hari arus yang dibutuhkan adalah 3,15 ampere dengan tegangan sekitar 7,2 volt. Sesuai dengan spesifikasi sel surya yang digunakan. Maka perhitungan payback periode

- $\quad$ Payback period untuk tabung $3 \mathrm{~kg}$

Total investasi

= Harga sel surya + harga elektroliser

$=\operatorname{Rp} 460.000,-+\operatorname{Rp} 160.000$,-

$=\operatorname{Rp} 620.000$,-

Penghematan uang per tahun

= biaya gas 1 tahun - biaya gas 1 tahun (dengan penghemat)

$=\operatorname{Rp} 925.000-\operatorname{Rp} 675.000$

$=\mathrm{Rp} 250.000$,-

Penghematan uang bersih per tahun

$=$ penghematan uang per tahun - biaya maintenance per tahun

$=\mathrm{Rp} 250.000-\mathrm{Rp} 46.800$

$=\mathrm{Rp} 203.200$,-

Payback period

$$
\begin{aligned}
& =\frac{\text { investasi }}{\text { penghematan uang bersih per tahun }} \\
& =\frac{\operatorname{Rp} 620.000,-}{\operatorname{Rp~203.200,-/tahun~}}=3 \text { tahun }
\end{aligned}
$$

- Payback period untuk tabung $12 \mathrm{~kg}$

Total investasi

Harga sel surya + harga elektroliser

$=\operatorname{Rp} 460.000,-+\operatorname{Rp~160.000,-}$

$=\operatorname{Rp} 620.000$,-

Penghematan uang per tahun

= biaya gas 1 tahun - biaya gas 1 tahun (dengan penghemat)

$=\operatorname{Rp} 1.420 .000-\operatorname{Rp} 994.000$

$=\operatorname{Rp} 426.000$,-

Penghematan uang bersih per tahun

$=$ penghematan uang per tahun - biaya maintenance per tahun 
$=\operatorname{Rp} 426.000-\operatorname{Rp} 46.800=\operatorname{Rp} 379.200$,-

Payback period

investasi

$=\overline{\text { penghematan uang bersih per tahun }}$

$=\frac{\text { Rp 620.000,- }}{\operatorname{Rp~379.200,-/tahun~}}=1,6$ tahun

\section{KESIMPULAN}

Berdasarkan hasil pengujian diperoleh kesimpulan sebagai berikut :

- Penambahan gas HHO menggunakan panel surya sebagai sumber daya DC pada kompor LPG dapat menghemat konsumsi gas LPG yang dibutuhkan untuk memanaskan air sehingga suhunya meningkat menjadi $45^{\circ} \mathrm{C}$ sebesar $27,7 \%$

- Payback periode yang dibutuhkan pada elektroliser menggunakan sel surya sebagai sumber daya DC pada kompor LPG $3 \mathrm{~kg}$ selama 3 tahun, sementara pada tabung $12 \mathrm{~kg}$ selama 1,6 tahun

\section{DAFTAR PUSTAKA}

[1] Wilda Zakiah, Amun Amri, dan Ahmad Fadli, "Pembuatan Prototip Dye Sensitized Solar Cell (DSSC) Berbasis Zat Warna Buah Senduduk (Melastoma Malabathricum L.) : Pengaruh Suhu Sintering $\mathrm{TiO} 2$ dan Konsentrasi Elektrolit", Jom FTEKNIK Volume 3 No. 1 Februari 2016

[2] Rizky Akbar Pratama dan Djoko Sungkono Kawano, "Pengaruh
Penggunaan Frekuensi Listrik terhadap Performa Generator HHO dan Unjuk Kerja Engine Honda Kharisma 125CC", JURNAL TEKNIK POMITS Vol. 2, No. 2, (2013) ISSN: 2337-3539 (2301-9271 Print)

[3] Nu'man dan Indra Herlamba Siregar, "Performa Mesin Dan Emisi Gas Buang Motor Bensin Berbahan Bahan Bakar Lpg Dengan Penambahan Gas Hho", JTM. Volume 01 Nomor 02 Tahun 2013, 271-276

[4] Ena Marlina, Slamet Wahyudi dan Lilis Yuliati, "Produksi Brown's Gas Hasil Elektrolisis $\mathrm{H}_{2} \mathrm{O}$ Dengan Katalis $\mathrm{NaHCO}_{3}$ ", Jurnal Rekayasa Mesin Vol.4, No.1 Tahun 2013 53-58

[5] Mohamed M. EL-Kassaby, Yehia A. Eldrainy, Mohamed E. Khidr, and Kareem I. Khidr, "Effect of hydroxy (HHO) gas addition on gasoline engine performance and emissions", Alexandria Engineering Journal (2016) 55, 243-251, DOI: 10.1016/j.aej.2015.10.016

[6] Akram Abdulameer A.A, dan Emad Talib, "Temperature Effect on Power Drop of Different Photovoltaic Modules", Journal of Engineering Volume 22 May No. 52016 pp:129-143

[7] E.M.G. Rodrigues, R. Melício, V.M.F. Mendes and J.P.S. Catalão, "Simulation of a Solar Cell considering Single-Diode Equivalent Circuit Model", Conference: Proceedings of the International Conference on Renewable Energies and Power Quality - ICREPQ'11 January 2011 